\title{
CLAP AND THE POX IN ENGLISH LITERATURE
}

\section{Discussion}

DR. J. D. Rolleston regarded it as a great honour to speak after Sir D'Arcy Power, and he re-echoed all that the President had said about the paper.

With regard to the nomenclature, it was interesting to note that, according to the Oxford Dictionary, which Sir D'Arcy quoted, the word "pox" seemed to be derived from the English "poc," whereas the word "clap" appeared to be derived from the French word " clapoir," meaning a bubo, or " clapier," meaning a brothel.

Sir D'Arcy raised the question why no disgrace attached to clap in ancient days. He, Dr. Rolleston, suggested it was due to the fact that clap had been in existence for all time. In Leviticus the " issues " alluded to were probably, in many cases, clap. That was in marked contrast with the history of pox, which was introduced into Europe at the end of the fifteenth century. He knew that Sir D'Arcy held the view that he did, that pox did not exist, in Europe at all events, before the end of the fifteenth century. It was still a disputed point. Professor Sudhoff held that it existed long before, and many writers, especially Rosenbaum, believed that all the allusions to lesions on the genitalia in ancient Greece and ancient Rome were syphilitic in origin. One great objection to syphilis having existed in classical antiquity was that held at a meeting in 1909 at the Royal Society of Medicine on Syphilis, in which Sir Norman Moore said that had syphilis existed amongst those highly civilised persons there would have been a description of general paralysis of the insane, whereas nothing of the kind was to be found.

As to the existence of syphilis in the Middle Ages, a very good argument against this was found in lay literature. He discussed that point in a paper he read at Bucharest some years ago, by pointing out that there 
was nothing to be seen in the works of Chaucer which could be interpreted as syphilis. The "moral" which was on the legs of the cook might be regarded as syphilis, but the speaker did not think so. He held, as did Sir D'Arcy, that much could be learned about syphilis, and about venereal diseases generally, by a study of contemporary lay writings. In his paper on the Medical Aspects of the Greek Anthology at the History of Medicine Section of the Royal Society of Medicine, I9I3, he had shown that the Greeks had described all kinds of sexual abominations, but yet there was nothing to suggest syphilis. There was little reference in lay literature about acute infectious diseases, with two remarkable exceptions, namely, the account given by Thucydides of the pestilence of Athens, which had puzzled many historians but which it was agreed by most was typhus. It was surprising how much it resembled typhus in our days in its high mortality and its acute onset, as well as containing the first description of post-infective gangrene, loss of limbs and of genitalia, post-febrile amnesia, and the immunity enjoyed by those who had had one attack. The other was Macaulay's immortal account of "the young and blooming Queen," the wife of William III., who had an attack of small-pox. Perhaps those who had not seen small-pox would think his description of the disease as "turning the babe into a changeling, at which the mother shuddered, and making the eyes and cheeks of the betrothed maiden objects of horror to the lover," was overdrawn, but it was exactly true.

Sir D'Arcy had mentioned Smollett. In the paper the speaker read to the Society in July, I934, he alluded to Smollett's "Travels through France and Italy." $\mathrm{He}$ came across a certain Professor "F." (Antoine Fize). $\mathrm{He}$ was a venereal specialist, not a very conscientious man, who practised at Montpellier.

With regard to Dr. Donne, there was an interesting line which appeared in Pope's paraphrase of Donne's "Satires":

"Time that at last matures a clap to pox, Whose gentle progress makes a calf an ox, And bring all natural events to pass,

Hath made him an attorney of an ass."

One gathered that some regarded pox as the terminav.p. I 5 
tion of a clap, and a similar view was prevalent in the eighteenth century, because Voltaire spoke of gonorrhoa in two senses; he spoke of a non-contagious gonorrhœa, which was probably leucorrhœa, and a disease which, if neglected, was converted into la vérole. Sir D'Arcy gave a striking example of the confusion, and there was another from John Aubrey who, in the seventeenth century, spoke of a certain Poet Laureate who contracted venereal disease, who " gott a terrible clap of a handsome wench that lay in the Axe yard at Westminster, which lost him his nose, with which many wits were too cruelly bold.'"

There was a similar confusion between clap and pox as with regard to measles and small-pox. In the sixteenth century the word "variola " was given as a translation of measles, a mistake made by William Clowes, surgeon at St. Bartholomew's, and by the man who had been described as the father of British pædiatrics, Thomas Phaer, who gave "morbilli" as the translation of small-pox.

Mr. Kenneth Walker said he was appalled at the apparent knowledge of English literature displayed by venerealogists ; he had not realised that the study of venereal diseases was associated with such profound literary knowledge, both British and foreign. He himself was only partly a venereal specialist, and he feared that the literary side of his studies had been sadly neglected. He would never attempt to compete with Sir D'Arcy Power, and it was not a surprise to find such knowledge in him.

He thanked Sir D'Arcy, and hoped that the account of this rich meal which he had provided would find its way into print. There were so many quotations and so many references that he had missed, during the reading, that he would like to be able to read again the excellent paper that Sir D'Arcy had just delivered.

SIR D'ARCY POWFr, in reply, said he was very much obliged to the members for listening to the paper, and for all that had been said in favour of it. He suggested that the two words were still in vulgar use, but members of the Society moved in such high circles that they did not hear them.

The President (Dr. Hanschell) said that he was sure all present felt very highly honoured at having Sir D'Arcy 
Power present to address them. His great distinction in surgery and as historian of medicine, himself a part of its history, were well known to all ; and, moreover, some of those present, including himself, had for Sir D'Arcy that affectionate honour, gained in student days, which disciples owe to their master. Sir D'Arcy had said that " pox" and "clap" had again come into vernacular use. It was true that in public urinals the terms were used in the notices posted there, but it was his experience that patients seldom used the terms; a man would say he thought he had the venereal disease, or that he thought he had gonorrhœa. But perhaps these formal terms were only a tribute of respect for the doctor on first meeting him, for it must be confessed, that on further acquaintance with him, the President's patients often became matey, describing with vivid vernacular simplicity the drama of how they had come by the present spot of trouble, and even paying him the sympathetic compliment of "You know, Doctor!" He, the President, had come across pox and clap in literature, in the course of desultory reading, long before as a medical student they were brought to his notice. He first came across the pox when struggling with the works of Dr. Donne, that famous Dean of St. Paul's and pet cleric of James I. Donne has a moving ode expressing his deep hurt in the soul against the woman he'd loved and who had given him the pox. And in our practice we still find often that dismay and mental pain and for the same reason. Donne also gives a short essay, in exquisite prose, on why the pox selects the nose. He concludes that a sense of fitness and propriety is shown by ending in one prominent member of the body what was begun in another prominent member. Shakespeare, too, had known and declaimed how the pox downed the nose; and Pope had had to go into hiding for a time on account of his couplet held to refer to Lady Mary Stuart Wortley Montague, who introduced small-pox inoculation. Pope wrote that her friends were libelled by her hate and poxed by her love. Pope did not disdain to pun and Lady Mary had snubbed him. A poet, like a woman, is dangerous to scorn. As to clap, he had first run across it in Butler's satirical epic poem "Hudibras," where the Puritan dissenters of the recent Cromwellian Commonwealth were ridiculed in the person of Hudibras, who was circumcised, not for religion, 
BRITISH JOURNAL OF VENEREAL DISEASES

but for "claps." It is still common folklore that the pox may destroy the nose. Probably all had heard the story illustrating this lore and the English love of punning. Two Ladies of the Town meet on the steps of the Lock Hospital when the bells are ringing in the New Year: "A happy New Year to you, my dear." dearie, and a happy new nose to you!"

"Thank you, dearie, and a happy new nose to you!" 